\title{
Reminiscence of My Research Works (6) Masanori KOBAYASHI*1
}

${ }^{* 1}$ High Energy Accelerator Research Organization, 1-1 Oho, Tsukuba-shi, Ibaraki 305-0801, Japan

(Received October 1, 2013, Accepted December 3, 2013)

\section{4. 電子ストーレジリング（PF リング）真空系}

今回は大型真空装置を建設する際の経験談を, 高エネル ギー物理学研究所 放射光実験施設 (PF, 現 : 高エネルギー 加速器研究機構物質構造科学研究所 放射光研究施設) の電 子ストーレジリング（PF リング）を例に挙げて書いてみよ う. 真空系の特長とその設計・建設に当たっての人間関係に も触れながら紹介する.

\section{1 電子ストーレジリングの例（性能競争）}

PF $2.5 \mathrm{GeV}$ リングの建設は 1978 年から開始された。 それ とほぼ同時期に米国ニューヨークのロングアイランドにある ブルックヘブン国立研究所 (BNL) でも放射光専用施設 (NSLS) を創設し2.5 GeVの電子ストーレジリング（X-ray Ring）を建設していた. いずれが先に放射光発生専用加速 器(電子ストーレジリング)から放射光を取り出し, ユーザー 運転を開始するかという海を越えての競争となったのは自然 の成り行きであった．結論を云えば PF が勝利した. 理由は いろいろあるが，NSLSのX-ray Ring ではよりシャープな 放射光を取り出すために電子ビームの角度と位置の広がりを 絞り込んで（エミッタンスの小さな）電子ビームを周回させ ることを目標の高い位置に置いたことが大きな理由として挙 げられる. 放射光源の性能としては, 輝度が高いこと, ビー 厶軌道が安定している(光源点がふらつかない)ことに加え, ビーム寿命が長く且つ故障しないことがある. NSLS では輝 度を高くすることを優先順位の高位置に置くという戦略目標 を採っていた．そのため電子ビームを絞り込むため 4 極電 磁石と 6 極電磁石の磁極をビームへ近づけた結果, ビーム ダクト断面は小さくコンダクタンスが制限された. また電磁 石の数密度も高くなったためポンプを適切に配する場所が少 なくなった．その結果ビームダクト内部の圧力分布は高くな ってしまうことは避けられないというリング設計であった.

加速器立ち上げの調整運転の重要なポイントは, 電子ビー ムをいかに短時間の調整運転で周回させ, 問題点を洗いだし ながら運転を持続できるよう調整できるかである．電子ビー ムを周回させることができればビームモニターを見ながら適 切な運転条件を見出すことが可能となるのだが，エミッタン スの小さな電子ビームの場合, 再現性よく周回させるに困難

*1 高エネルギー加速器研究機構（３３05-0801 茨城県つくば市大 穂 1-1)
が多く, 安定な運転条件を確立するには時間がかかる．これ は当時の計算機の性能と制御プログラムの状況での話であ り，約30年後の現在のビーム制御技術は各段に進歩してい る. PF はNSLSよりエミッタンスが大きい反面, ビームを 安定に短時間で周回させることを最優先とし, それに適した 磁石配列設計とした。 その結果 NSLSより短い時間で電子 ビームをストーレジできた. 一旦電子ビームを周回させる運 転条件を確定できれば, 発生した放射光がダクト壁面を照射 しその積分照射量に反比例して光脱離が減少し（ビームク リーニング効果とも云う）リング内圧力が下がり，ストーレ ジビーム電流の寿命も長くなる. その結果より大きな電流值 で電子をストーレジできるようになる．このようなポジティ ブフィードバックが PF リングの運転では働いた。ほぼ同時 に電子ストーレジリングの建設をスタートした NSLSのXray Ring と KEK の PF リング二つの電子ストーレジリング の立ち上げ運転成功の違いは, 原因には他にいろいろある が, 後で説明する電磁石配列とその結果の真空ポンプ配置に 因るところが大きいと云ってよい.

\section{2 電子ストーレジリング真空系の設計に際して（有益 であった設計思想)}

PF の電子ストーレジリングの目標とする性能は, 最先端 加速器（例えてみれば Formula car; F1）のそれではなく共 同利用の加速器（あたかも高速道路を $150 \mathrm{~km} / \mathrm{hr}$ で定時運行 する高速バス）にふさわしい性能とすることと私は理解し た. 設計に当っての考え方や態度について参考になった本が 二つある. 一つは，正しい書名を忘れてしまったのたが，佐 貫亦男氏による飛行機や武器についての著書が参考になっ た、それによれば, 民族の特徵が最も端的に現れるのは武器 であり特に戦闘機の設計には民族の哲学がある，という内容 であったと記憶している．敵機の銃撃から守るべき最優先の 箇所は戦闘機のどこか. エンジンか操縦席か燃料タンクか. 最優先の性能は飛行速度か, 上昇速度か, 高高度飛行か, 旋 回性能か, 積載量かなどなど. 各国の戦闘機製造技術だけで なく燃料の供給状況も含めて設計が決まっていることなど, 興味深かった. もう一冊は辻泰先生に教えて頂いた「マンハ ッタン計画」という早川書房からの本であった。マンハッタ ン計画の目的そのものを評価するわけではないが，いかにウ ランの分離を速やかに実現するか, 質量分析法, ガス拡散 法, 遠心分離法, 化学処理法という異なる方法を並行して進 め, 原理的に優れているのか, 効率まで含めて工学的に優れ 
ているか，目標とする時点まで如何にしてウラン濃縮を間に 合わせるか, 分離操作をする人材の知的レベルやそれまでの 経験の種類, 供給可能人数など, クールに検討評価する視点 と決断, 責任の負い方など大変興味深かった。私は大学の研 究室で実験装置を設計し実験する立場から突然大型システム を設計する立場に替わったため，設計に当っての基本的姿勢 に不安があったが，プロジェクトとはどういうものかをこの 本で坦間見た思いがした，大型真空装置を設計する基本的態 度と姿勢が決まり, 背中を支えてもらったと思っている.

ハードウェアで構成するシステムデザインについての教育 を大学ではどのような内容で教えているのだろうかと興味を もったが，次に説明するように単年度予算を着任後の 3 年 間で執行するという束縛条件の下で設計・製造・設置と続 き，完成後はより高い性能を狙っての改善に明け暮れたた め, システムデザインとはかくあるべしということを未だ学 習できていない.

\section{3 真空系設計当初（概算要求と矛算執行）}

1979年にそれまでの東大生産技術研究所から高エネル ギー物理学研究所に席を移して電子ストーレジリング真空系 の設計を始めた．PFの創設は着任前年の1978年から1981年 までの 4 年計画として予算措置がなされていた. 予算は建 物関係, 加速器関係設備 $[2.5 \mathrm{GeV}, 400 \mathrm{~m}$ の電子リニアッ クおよび $2.5 \mathrm{GeV}, 500 \mathrm{~mA}$ の電子ストーレジリング」，放射 光利用実験設備に分かれている. 電子ストーレジリングの真 空に関する概算要求の内容についてまったく知らないという 状況のまま私は着任したのである，概算要求書は東大核研の 電子シンクロトロン (ES) および IN-SORの経験や高エネ 研のプロトンシンクロトロン（PS）の経験を基にして作ら れたのであろう。電子ストーレジリング真空系の概算要求の 部分は PSの真空担当であった故堀越源一先生も関係して作 成されたと想像する. 大学の研究室の年間予算のざっと 2 桁強ほど大きな予算を 4 年間で執行して, 周長 $187 \mathrm{~m}$ の電子 ストーレジリング真空系を作らなければならないという状況 に立ち至ったのであった，事態に対する私の理解がそこまで 至っていなかったとはいえ，扔ちょこちょいというか，思 えばかなりの度胸であった，知らぬ者の強みかもしれない。 電子ストーレジリングの真空以外の他の部門では，真空系の 発注作業に先行して電磁石の設計と発注, 大電流高周波源々 空洞の設計と発注が初年度から進められていた。それぞれを 担当する責任者は高エネ研加速器研究系から異動してきた実 経験のある方々であった。

予算書を見て二つの発見があった。 入射器と呼ばれる（長 さ $400 \mathrm{~m}$ ，エネルギー $2.5 \mathrm{GeV}$ ) 電子リニアックと電子ストー レジリングとは $140 \mathrm{~m}$ ほど離れて配置されているのだが，そ れらの間を結びリニアックからの電子ビームをリングに導く “ビーム入射路”の真空に関する予算が抜け落ちている，こ れが第一の発見であった．二つ目は，周長 $187 \mathrm{~m}$ のリング真 空系の規模に対して，予算計上の項目名と予定金額のバラン スが良くない，ということであった．正直，どうしてこんな 予算書を作ったのかと不満があったのを思い出す．当時の光 源系研究主幹であった故冨家和雄先生に申し入れたが，概算 要求の申請項目は変更できないこと, 予算の過不足は各項目
の間で調整するしかないが $10 \%$ を超えるような变更は新た な変更申請となること，というのが回答であった．予算の抜 けについては，さすがに放射光実験施設の執行部でも慌てた ようである. 光源研究系以外の系にも相談したようで，しば らくしてから「リング真空系予算の一割に相当する額だけを 確保したから，それで入射路真空系を何とか作れ」というこ とになった．赴任時のこのような初期条件の下で電子ストー レジリング真空系の設計はスタートしたのであった.

真空に関する概算要求の予算費目金額のバランスに難があ ることの発見については，次に多少詳しく書いてみよう。電 子ストーレジリング真空系の設計で最初に検討することは, 当然のことながら達成すべき性能である，その性能とは電子 ビームを(a) 十分な強度で, 且つ(b) 十分なストーレジ寿 命を確保し，（c）光源点（すなわち電子軌道）が時間的に安 定していること，（d）故障が無く予定運転時間中に真空卜 ラブルで真空を破ることがないこと，(e) 圧力の履歴を記録 し過去のデータを必要に応じて参照できること, (f) 主要機 器の動作を遠隔で操作ができること，などである.

(a)についてはビームダクトを照射する放射光のパワー （ダクトに沿って35 W/ cm@500 mA ビーム電流）を受け止 めることが可能となるようダクトの外周側に冷却水水路を用 意すること, 放射光取出し部（二股の枝状に分かれる; クロ ッチ）ではダクト壁より約一桁強い放射光パワー密度の入射 となるのでそのパワーを受け止める機能・構造を用意するこ と, (b)については所定のストーレジ電流に対応する光脱離 があっても $10^{-7} \mathrm{~Pa}$ の真空を確保できる排気速度をもつポン プを選定し適切に配置すること，（c）については排気，ベー キング，放射パワー入射などを原因とする設置ダクトの位置 ずれが運転中に起こっても，固定点であるべきビーム位置モ ニターにストレスをかけないようにダクトを正規位置に固定 する構造を用意すること，(d)についてはダクトや採用した 構成部品の信頼性が十分に高いこと，ハイブリッドな材料を 使いこなすデザインとすること，市販品の中から高信頼性の ものを選択することで保守部品点数を少なくして維持費負担 を小さくすることなどがある。これら要求項目の (c) と (d) は云いかえれば，電子ストーレジリングの真空性能を熟慮す るのと同様にリングダクト類の機械的性能についても重要視 して設計するということである。(e)(f)については，およそ 90台のイオンポンプ（分布型＋通常型）それぞれの動作状 況のチェックとON/OFF などリモート操作, 約50台の BA 型電離真空計の読み出し, 6 台の粗排気系ポンプのリモート 操作, 異常圧力発生時に備えインターロックによるゲートバ ルブの開閉作動とそれをリモートで監視するシステムを作る ことを意味している.

共同利用実験のために放射光を供給する役目を担う電子ス トーレジリングが以上の $(\mathrm{a}) \sim(\mathrm{e})$ までの機能を十分に発揮す るようにイメージを明確に持ち，すなわち $(\mathrm{a}) \sim(\mathrm{c})$ について はビームダクトの設計, (d)については適切な選択, (e) (f) については将来ユーザー運転が始まったときのビームライン 側からの大気洩れ事故も想定するなど, 電子ストーレジリン グ真空系を設計する段階でも個人的嗜好を持ち込まないよう 
に，クールな態度（or 配慮）を心がけた。

着任初年度の設計に没頭していた頃, 光源研究系の故冨家 和雄主幹から早く予算を執行するよう作業を急げ，とたびた び注意を受けた。当時の主幹の心を想像するに, 加速器にま ったく関係のない研究室で真空の研究をしてきた若い助教授 は机の前で何を考えているのか，ポンプとかバルブとか市販 されている物品の中から適切且つ必要な数を割り出し発注す ればよいのに，ということではなかったか。研究室では扱わ ない大きな予算の執行は競争入札が原則であり, 入札の告 知, 仕様説明会, 入札, 発注という手続きとその後の製造を 考えると遅くともを 9 月初旬には入札までを終えておかな ければならない。にもかかわらず処理が “遅い”と見られて いたと思う。しかし私は, システムは物品の集合体では断じ てない，そこには思想がなければならないと強く思ってい た.なにせ全ての事柄が初めての経験なので, システムにつ いての自分の考えの正しさを声高に主張も出来なかったが, 先に述べた 2 冊の本に書かれていたシステム設計者の“姿 勢”は自分の考え・方針を支えてくれるものであった．完成 は 3 年後であり, 着任年度に発注する物品と次年度, 第三 年度に順次設計・発注する物品とのマッチングが良くなけれ ば，無駄な物品とまでは云わないにしても並みの製品を集め 並べた真空系となってしまい，とても本来あるべきシステム というものにはならない。いろいろな声が周りから聞こえて はきたが，自分の考えを若さにまかせ通させてもらった． 3 年後に完成させる真空システムの構想が決まれば(決めれば) 必要なコンポーネントの開発や物品の調達に大きな本質的な 困難はない，大わらわでビームダクト等の図面を画き，開 発・製造を受けたメーカーと交渉を進め，年度途中で設計変 更するなどの行きつ戻りつをすることも無く，結果として単 年度予算の執行に遅れをとるという失態もなく処理していっ た。

その年の夏ごろ（私にとっての初年度）に, 発注作業の遅 れの原因は真空グループの人手が足りないためでは，と心配 された高良和武施設長から「必要ならアルバイトを雇っては どうか」と言葉をかけていただいた。「孫悟空の話にある “抜いた毛にフーっと息を吹きかけると自分と同じコピー猿 が生まれる”というのは“設計への思いが自分と同じだから 役立つ”のであって，アルバイトの人にゼロから設計方針や 注意事項を縷々説明し理解してもらうだけの時間がもったい ない.自分でやります。ご心配はありがたいのですけど」と 答えた．頑固な奴だ，という顔をされた．ツーカーで相手と 自分の考えの相違がわかり，今何をしたいのか明日何が必要 なのかを理解できる，そのような人材を確保するには仕事の 規模も考慮に入れた採用タイミングがある，ということを実 感した。このような人に関することもマンハッタン計画の本 には書かれていた．大型計画での人の採用は予算書の中に書 き込まれるためか，概念設計や技術上の設計段階では新規の 採用は無い。国際的な規模の加速器, 例えば International Linear Collider ILCでは, Central Design Group が概念設 計・技術設計を検討し作り上げていて，計画が本格的にス タートしてから人の（新規採用を含め）異動が起こるようで
ある・

概算予算に抜け落ちていた入射路真空系についても，当時 の主幹団の努力と工夫によって十分ではないが翌年の1980 年に措置された。それを受けて入射路真空系を全面的に設計 し施工したのは同年に着任した当時助手の北村英男君であっ た。少ない予算の中で IN-SOR での経験を活かして入射路 真空系を設計し, 業者と交渉し, リングの真空ダクトの設置 接合の時期と相前後して完成させた. さらに入射グループと 交渉しながら入射用パルスマグネット（キッカー電磁石 $\times 4$ とセプタム電磁石 $\times 2)$ 用真空槽も直前に完成させた．検討 している内容と経過について時々話し合いをしながらの作業 であったが，入射路真空系の仕事を全面的に任せ，リングダ クトの製造設置と同時進行で完成出来たのは，幸運な人的組 み合わせの結果であったと思う.

\section{4 設計の工夫・特徵}

設計上の大きな一歩に，挿入型クロッチアブソーバーの考 えがある、放射光パワーを受け止めるために，英国の Daresbury 研究所の Synchrotron Radiation Source (SRS) リング $(2.0 \mathrm{GeV})$ では水冷した銅の板をステンレス鋼製ダ クト内の外周に配置している。ビームエネルギーがより高い ドイツの Deutsches Electron-Synchrotron（DESY），米国 Stanford 大学の Stanford Synchrotron Radiation Lightsource (SSRL), NSLS, Cornell 大学の Cornell Electron Storage Ring (CESR) ではアルミ合金製の水冷管内蔵型断面のビー ムダクトを採用している．放射光は偏向電磁石部ダクトに斜 め入射するが，偏向電磁石下流部でビームダクトから放射光 が分岐する箇所（クロッチ部）では分岐部壁に放射光が垂直 入射することが避けられず，パワ一密度がダクト側面のパ ワー密度に較べ一桁ほど大きくなる，CESR ではビームエネ ルギーが高いため高エネルギー成分の多い放射光が発生され ることもあって，クロッチ表面でパワーを受け止めきれな い. 対策として吸收係数の小さなべリリウムやカーボンの層 で低エネルギー放射光のパワーを受け止める. 一方高エネル ギー放射光はその層を透過し，その後ろ側に用意した水冷銅 ブロックでパワーを受け止めるという sophisticated design を検討し発表していた。しかしながら偏向電磁石の磁極に挟 まれた空間のクロッチに割り当てられる狭い空間にこの構造 を持ち込むのは非常に困難であるだけでなく，異種材料の接 合と接合面を通しての熱伝達の確保，長期信頼性の確保，さ らにアルミ合金製ダクトに複合材料製のクロッチを溶接しな ければならないという深刻な問題があった。

いろいろと考えた末に，放射光を受け止めるための放射光 アブソーバー（クロッチアブソーバー）をアルミ合金ダクト とは別体として製作し，フランジを使ってリング外周側から ダクト内に挿入するという demountable 構造とすることに 思い至った．このデザインにすれば偏向電磁石部ダクトの製 造とクロッチアブソーバーの製造年度が異なっても問題とは ならないし, 将来性能向上としてエネルギーアップがあって もダクトを修正改造する必要は無く，単にクロッチアブソー バーの材質と構造を変えれば済む。.このデザインはハワイで 開催された日米放射光加速器施設の国際セミナーに㧍いて冨 
家主幹からPFの案として発表された. NSLSの当時の責任 者であった Dr. Steenbergen から PFのアイディアを使いた いと会合の後に申し入れがあったと帰国した主幹から聞かさ れた (Ref: M. Kobayashi, G. Horikoshi and H. Mizuno: Proc. Japanese/USA Seminars on synchrotron radiation facility, Honolulu, USA, 1979, 177 (1980) 111). その後，クロッチ アブソーバーを demountable 構造として偏向電磁石下流部 に外側横から挿入する方式は，KEKのアドバンストリング $\mathrm{PF}-\mathrm{AR}$ の高性能化改良に抢いても採用され，台湾の National Synchrotron Radiation Research Center (NSRRC) で 建設が進められ2013年中に立ち上げ運転に入る予定の TPS でも採用している.

設計上重要なもう一つの一歩に, ビームダクトの電磁石に 対する位置決めがある．この件については別稿で具体的に説 明しよう.リング全周にわたるビームダクトの位置決めにつ いて，設計当初から検討した。ベーキングをしないリングと は異なり，in-situベーキングを（場合によっては多数回） 行っても全てのビームダクトが正規の位置に微調整などなし に留なるように設計した。すなわち, ベーキングによってア ルミ合金製ダクトが延び方向と範囲を規定しておくという設 計方針によってダクト同士を接続するフランジ近傍に必要と なるべローの数を減らすことが出来ただけでなく，放射光を 取り出し放射線シールド壁外側の実験ホールへ導く基幹チャ ネルの位置決めと再現性も確実なものとできた.

仮想実験として，長いベロー配管をつないでリング状にし て平らな台上に置く．このベローリングを排気するとリング はどのようになるか？ ベローは大気圧に押されて縮みリン グの直径は小さくなることは想像できるであろう. 一周 187 $\mathrm{m}$ のリングであってもリングには複数のベローが入ってい るのでリングダクトは周の内径方向に移動することが起きる と予想した. リング半径方向への移動が最も大きく現れるの は電子軌道曲率半径 $8.66 \mathrm{~m}$ の偏向電磁石部ダクト（B ダク ト）である，B ダクト設計にあたっては，リング半径方向へ の移動を抑制するとともにリング周方向へのベーキング時の 移動方向を制限するために基準（孔と長溝）を設け，ビーム ダクトの位置決めを明確にした設計とした.

\section{5 設計に続く建設までの日々}

自分が設計している電子ストーレジリング真空系が加速器 の実情や経験から妥当なものか否かを判断することは, 加速 器の運転が未経験の私には出来なかった.

加速器の現物を目の当たりにしたのは真空に関する国際会 議 IVC-7（Vienna, 1977）の帰路，辻泰先生と共に訪問した ジュネーブの CERNでの Intersecting Storage Ring (ISR) が初めてだった。それは直径約 $300 \mathrm{~m}$ のリングで巨大な延々 と続くコンクリート製トンネル内に設置された数多くの電磁 石の列であり, 大学や工場などにある装置とは異質そのもの であった，互いに逆周りに周回するビームが交差する箇所は 他の箇所に較ベトンネルの天井も幅も大きく，周回部に較べ れば電磁石配置がまばらなため斜めに交差しているビームダ クトを間近に見ることができた。その印象を一言で言えば 「こんな巨大な真空装置が $10^{-9} \mathrm{~Pa}$ になっているとは信じら
れない」であった．また設計だけでなく多数のビームダクト を製造し設置するという人々の情熱とエネルギーの持続に感 銘を受けた。また自分には CERNの人々のようなエネル ギーが足りないな，と感じたことを思い出す.

その後1977年頃に故堀越源一先生の案内で高エネ研の12 $\mathrm{GeV}$ シンクロトロンを見学する機会があった。薄暗いコン クリートのトンネル内に多数の青色に塗られた大きな電磁石 が列をなして並んでいて，その隙間にわずかにステンレス鋼 製のビームダクトが見えていた．大学には無い大型のイオン ポンプで強引に排気している真空装置という印象であった.

シンクロトロン加速器を実際に設計し運転しての経験をも っている堀越先生に，PF 電子ストーレジリング真空系の基 本設計と技術と予算を考慮した実情を説明して，たびたび評 価していただいた．堀越先生の物理屋特有の楽天的発想（上 手くいかなければ，変えればいいさ）に全面的には付いてい けないこともあったが，設置組み立てにどれほどの人力が必 要か，その時間的対策など，多くのことを教えていただい た. もちろん, 楽天的とも思えるいくつかの発言は真空科学 だけでなく構造力学に基づいた解析的手法で得た数字に裏付 けられてのものであった．堀越先生と故水野 元助手は，私 の着任前の1978年の初年度にアルミ合金製真空ダクトを試 作していた。レーストラック断面のアルミ合金ダクトの大気 圧による変形量の確認, ベーキングの影響と課題, 溶接およ び異種金属接合の信頼性などをチェックしていた.ベーキン グ温度を $200^{\circ} \mathrm{C}$ 近くまで高めたところ, ワイドスパンのアル ミ合金ダクトは大気圧に抗しきれずレーストラック直線部が 相互に接するまで潰れた。所内では「堀源先生のダクトが潰 れた」と話題になっていた. 3 年後に各種電磁石に挿入設置 されたアルミ合金ダクトに対するベーキング温度の管理と制 御はこの経験に基づいてなされ，全てのアルミ合金ダクト実 機での変形トラブルは皆無にできた.

また，堀越先生の率いる PS 真空グループの技官の方々 (敬称略, 山口博司, 久保富夫, 久松広美）には大いに助け ていただいた．山口氏には現場組み立てで起こった数々のト ラブルとその対策や注意点, 久保氏には $\mathrm{CF}$ フランジの信頼 性向上など機械構造の視点からの予備テスト，久松氏には多 数の遠隔操作可能な小型イオンポンプ電源の開発と状態監視 について, 大型加速器を現実に運転維持している数々の経験 に基づいた提案や助言があり, 電子ストーレジリング真空系 設計の具体化で大きな助けとなった.

\section{6 電子ストーレジリングの性能実現のために}

一旦電子ビームの安定軌道を見出し周回させることができ た時の放射光源としての性能の優劣は, 単に明るいだけでな くその明るさが時間とともに減少する割合が少ないことが優 れた光源の条件であることは先に述べた，すなわちビーム電 流 $I_{\mathrm{B}}$ とビーム寿命 $\tau$ との積 $I_{\mathrm{B}} \tau$ の大小で評価できる. 具体 的には PF リングの $I_{\mathrm{B}} \tau$ の值は運転開始から数年たって 830 A min を達成し，最大值は〜 $1200 \mathrm{~A}$ min を記録するまでに なったが，この值は世界の電子ストーレジリングのなかでも 最も大きな值である， $I_{\mathrm{B}} \tau$ の高い值を達成できるためには大 電流をストーレジしてもリングの平均真空が良いことを意味 している. 加えて適切な運転条件を見出した軌道・高周波・ 
モニターグループを含む運転チームの貢献がある.

ここで， $I_{\mathrm{B}} \tau$ の中身を書き直し，より具体的な検討項目を 真空の視点から書き出してみよう．Gを加速器に固有の条 件である偏向半径 $\rho$ とビームエネルギー $E_{\mathrm{B}}$ から定まる定数 として積 $I_{\mathrm{B}} \tau$ を書き直すと

$$
I_{\mathrm{B}} \tau=G\left(\rho / E_{\mathrm{B}}\right) \times S_{\mathrm{e}} / \eta
$$

となる． $I_{\mathrm{B}} \tau$ を大きな值にするには, 系の実効排気速度 $S_{\mathrm{e}}$ を大きくするようにリングの排気ポンプの種類, 台数, 配置 を最適化すること, 且つ光脱離イールド $\eta$ を小さくするよ うな表面処理やダクトへの放射光照射条件に工夫をこらすこ とが必要とわかる，前者は真空工学の課題であり，後者は表 面科学の課題である.

ポンプ配置のより適切な位置を検討するにはリング内の圧 力分布がどのようになるかを知らなければならない.リング 内部で光脱離量 $Q_{\mathrm{ph}}$ によるガス放出量が大きな箇所（也めて 近傍）へポンプを配置することは実効排気速度 $S_{\mathrm{e}}$ を大きく 確保することとに等しく， $Q_{\mathrm{ph}}$ と $S_{\mathrm{e}}$ を双方の検討が電子ス トーレジリング真空系設計の最初の作業である.

ポンプの配置位置と排気速度, ビームダクトに沿った各位 置（x）でのコンダクタンスとを考慮したダクトの各位置で の実効排気速度 $S_{\mathrm{e}}(\mathrm{x})$ を求めた。ここで云うコンダクタン スはダクト断面を楕円近似した十分に長いダクトのコンダク タンスから求めた単位長さ当たりのコンダクタンスのことで ある.ダクトには複数の排気ポートが配置され, 位置 $\mathrm{X}$ で は排気ポート $(\mathrm{A})$ と排気ポート $(\mathrm{B})$ へとう 2 方向へ気体分 子はコンダクタンスに比例して排気される.したがって，位 置 $\mathrm{X}$ でのコンダクタンス $C(\mathrm{X})$ は $\mathrm{X}$ での $(\mathrm{A})$ へ向けてのコ ンダクタンス $C_{\mathrm{A}}(\mathrm{X})$ と $(\mathrm{B})$ へ向けてのそれ $C_{\mathrm{B}}(\mathrm{X})$ の和と なる．このような考えで求めたコンダクタンス $C(\mathrm{X})$ と排 気ポートの構造を考慮した実効排気速度 $S_{\mathrm{e}}$ とからダクト内 の各位置 $\mathrm{x}$ における実効排気速度 $S_{\mathrm{e}}(\mathrm{x})$ を求めた.

一方, ガス放出負荷原因となるダクト壁面への入射光子数 $N_{\mathrm{p}}(\mathrm{y})$ もビームダクトの幾何学的数值と配置から求めるこ とができる.

これら $N_{\mathrm{p}}(\mathrm{y})$ と $S_{\mathrm{e}}(\mathrm{x})$ が分かれば， $\mathrm{x}, \mathrm{y}$ それぞれについ て $N_{\mathrm{p}}(\mathrm{y}) / S_{\mathrm{e}}(\mathrm{x})$ を重ね合わせることでリングダクトに沿っ た圧力分布を求めることができる。しかし， $\mathrm{cm}$ 単位でダク

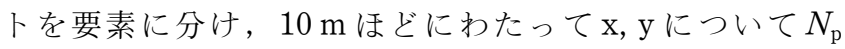
$(\mathrm{y}) / S_{\mathrm{e}}(\mathrm{x})$ 求めて重ね合わせるのは手計算ではできず， $\mathrm{PC}$ のメモリの上で重ね合わせるしかない，PFの真空系を設計 していた当時は手近で使える PC は世の中に無く, 計算機室 のカードとテープを使って計算する時代だったので, 計算機 の使用予約時間をとることが出来なかった。止むを得ず “イ メージ”をグラフ用紙と頭の中に画いて最適なポンプ位置を 決定した.

イメージの基になっているのは「気体分子はどこに居たい と感じているか，何処に移動したいと思っているか」という ような文学的ともいえる想像であった. このようなイメージ を持てる？ようになったのは2.2に書いたように，1960年代 後半に行っていた油分子の非定常流実験においてバーナーを
用いて余計な油分子を焙り出していた日々の経験に基づいて いるように思う。細くて長い配管 $(20 \mathrm{~mm}$ 直径のガラス配 管でも電子ストーレジリングの $130 \mathrm{~mm} \times 70 \mathrm{~mm}$ の変形 8 角 形のビームダクトでも）の中を動き回る分子の挙動は（平均 吸着時間 $\tau$ に違いはあるが）似ていることが起こっている, と感じていたからと思う。

1980年代の前半にようやく EPSON, Tandy, 少し遅れて Apple (Macintosh), Hewlett-Packardの PC が世の中に出回 るようになり，BASICをプログラム言語として手元で圧力 分布を計算することが可能となった．私も科研費で手に入れ た Hewlett-Packard 社の PC と HP-BASIC 言語を用いての 計算プログラムを作成した. 放射光による真空系負荷の分布 $N_{\mathrm{p}}(\mathrm{y})$ と局所に配置したポンプおよび分布排気ポンプ DIP さらには断面の異なるビームダクトのコンダクタンス $\mathrm{C}(\mathrm{X})$ も取り达んだ一次元の有限要素法を用いたプログラムであ る. 典型的な例は, 偏向電磁石 1 台とその下流の 4 極およ び 6 極電磁石, ビーム位置モニター, 次の偏向電磁石まで を 1 セクションとする計算プログラムで, このプログラム を用いて圧力分布を求めた。 この例の場合でも, 当時の PC の処理能力では計算には昼夜ぶっ通しで 5 日ほどの時間が かかった. 計算機の演算速度が遅かっただけでなく, 当初組 み込まれていた小さなメモリ容量では場所毎の計算結果を記 録するには不十分なため加算途中で計算が止ってしまうこと も起こった. メモリ容量に見合う程度に差の小さな計算結果 を省くあるいは無視という処理を加えての計算であったのだ が. 演算速度もメモリ容量も桁違いに進歩している現在では 想像しがたいことと思う. 幸いなことに, アナログ的に頭の 中でイメージした圧力分布は PCによるシミュレーションで の最適化の結果に近いものであることが判明し，ほっとした のを思い出す.

図 1 に一次元有限要素法による計算結果を示す。電子ビー

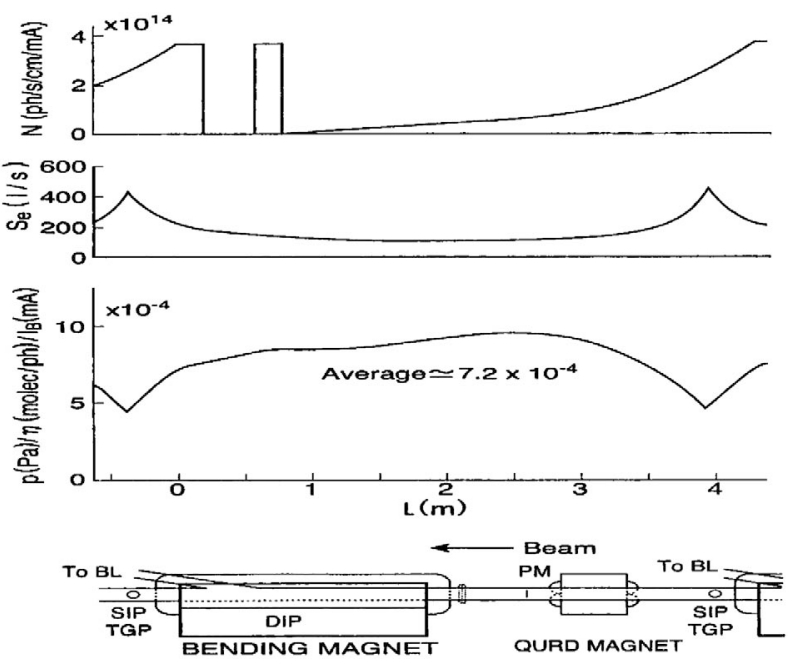

図 1 (上段) : PF リングのノーマルセルの負荷（ビーム電流 $1 \mathrm{~mA}$, ダクト単位長さ当たりの光子入射強度）分布, （中段）：コンダクタンスも考慮した実効排気速度の分 布, (下段) : 圧力分布（光脱離イールド $\eta$ とビーム電 流 $I_{\mathrm{B}}$ で規格化 $)$. 
ムは図の右から左へ進んでいる。 また偏向電磁石の下流端を 横軸のゼロとして表している．圧力は負荷原因となるビーム 電流 $I_{\mathrm{B}}$ 抢よび光脱離係数 $\eta$ で規格化して表してある. した がって，実際のリング内の圧力を推定するには，ストーレジ 電流 $I_{\mathrm{B}}$ と到達していると思われる光脱離イールド $\eta$ をグラ フの值に乗ずればよい， $\eta$ と $I_{\mathrm{B}}$ で規格化した $\mathrm{PF}$ のノーマル セルと呼ばれる範囲の平均圧力 $p[\mathrm{~Pa}] / \eta[\mathrm{molc} / \mathrm{ph}] / I_{\mathrm{B}}[\mathrm{mA}]$

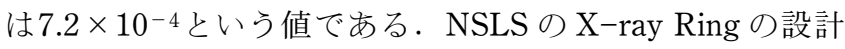
值をパラメータに選び，彼らの設計した真空系について図 1 と同じシミュレーションを行ってみた．低エミッタンスを狙 って電磁石を配列したラティスからなる彼らのリングのノー マルセル部の狭いダクト内の規格化平均圧力值は $3 \times 10^{-3}$ となり，PFのそれより明らかに 5 倍弱高いという結果を得 た。すなわち，同じ条件ならビーム寿命が PF の $1 / 5$ になる ことを意味している. 実際, X-ray Ringのビームダクト内 圧力は PF より高く，その結果ビーム電流が直ぐに減少する ためリング運転に伴う放射光照射によるクリーニング（光焼 きだし，あるいはビームスクラブと呼ばれる）もなかなか進 まない状況となっていた. 性能競争となっていた二つのリン グ運転の実情は, 圧力分布のシミュレーションの計算からも 裏付けられた。

図 2 の排気速度の図では, 偏向電磁石直下流に配置したチ タンゲッタを内蔵するポンプポート部の排気速度が大きく, 偏向電磁石内に配置したDIPの効果が小さいように見え る.しかし圧力曲線を見ると DIP offによって系内の圧力が 高まりDIPの効果が大きいのが見て取れる.

\section{7 リングの圧力計測と表示}

リングダクトに沿っての圧力分布をシミュレーションで画 くことはできたが，電子ストーレジリングを運転し放射光が 発生しているときの実際の圧力分布はどのようになっている かを測定する必要がある.リング周長 $187 \mathrm{~m}$ に B-A 真空計 を48個取り付けた．ここで云う電離真空計は後に稿をあら

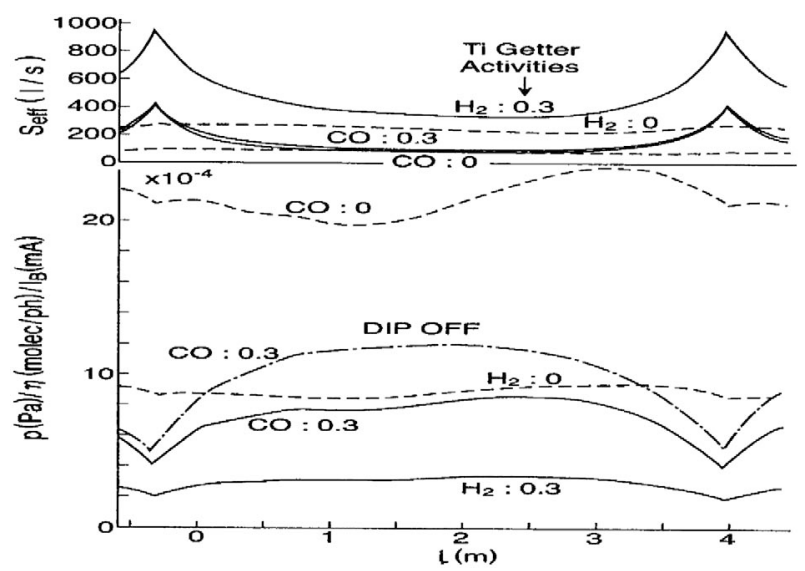

図 2 一酸化炭素抢よび水素に対するダクトに沿った系内の実 効排気速度分布（上）と規格化した圧力分布（下）. 排 気ポート部にはチタンゲッタとイオンポンプ（図では 2 箇所), 偏向電磁石部に分布型イオンポンプ DIP (図横 軸の $0 \sim 1.8 \mathrm{~m}$ の間に） が配置されている. パラメータ はチタンゲッタの吸着確率 $s\left(\mathrm{CO}\right.$ および $\mathrm{H}_{2}$ に対して $s$ $=0.3$ の場合と $s=0$ の場合). 下図の一点鎖線は（ $\eta$ と $I_{\mathrm{B}}$ で規格した）圧力 $p$ へ DIP offの影響を示す.
ためて説明するが，特別に注意を払ったものである．真空計 相互間の距離は平均で $3.6 \mathrm{~m}$ ほどになる.リングトンネル内 は運転中には放射線レベルが高くなるので, B-A 真空計回 路はリングトンネル内には設置できず，リング地下の機械室 にリングに沿って配置した.

ベーキングを済ませリング運転をスタートした時, ビーム 電流がゼロのバックグラウンドでは $10^{-8} \mathrm{~Pa}$ 台に達していて も，ビームクリーニングの効果が未だ小さいリング運転の初 期に拈いては光脱離が大きく数ミリアンペアのビーム電流で あっても圧力が $10^{-4} \mathrm{~Pa}$ 台まで上昇することが起こった。す なわち，測定すべき圧力領域は $10^{-9} \mathrm{~Pa} \sim 10^{-4} \mathrm{~Pa}$ と 5 桁に なる. その当時イオン電流計測用のアンプはダイナミックレ ンジが 4 桁のものはあったが 5 桁のものはなかった．当時 市販されていた電離真空計の回路は自動レンジを取り入れる ことで 4 桁の広帯域対応としていた。自動レンジの真空計 からの圧力データを取り込む場合に值と桁の両者（指数と仮 数）を読み取る必要があり，当時の PC (NEC PC9800)の 性能で圧力をグラフ表示するには難があった.

助手の北村英男君と相談しながら，真空計のアンプを 4 桁の固定レンジとして值だけを読み取ればグラフ表示の負担 が少なくてすむことから，固定レンジのオペアンプを用いる 方式とした。その代わり，立ち上げ時には一桁高い領域にプ リセット，運転が進んでビームクリーニングの効果が現れて きたら一桁下の領域にプリセットすることを手動で行うこと にした. 各真空計からは常時垂れ流しでイオン電流值を吐き 出させ, 新規開発のデータ収集回路を用いて真空計からの出 力をシリアルに読み回ることでデータを集めることにした. ビーム入射路用真空計を含めると50数台になる B-A 真空計 回路を上記のような考えに基づき特注した.

リングの48台に加えビーム入射路の電離真空計の出力を 読みに回る時間は切り替え器の性能で決まるが, 切り替え器 を含む読久取りの性能は当初は数分ほどかかったが，やがて 数十秒さらには数秒というように年と共に向上していった. データの画面表示は縦軸が対数の圧力，横軸をリング一周に 相当する真空計の配置とした．圧力のグラフ表示画面は中央 制御室の中央に置かれ，Torr 表示で $10^{-11}$; 濃青, $10^{-10}$; 青, $10^{-9}$; 緑, $10^{-8}$; 黄, $10^{-7}$; 赤というように（真空の 専門家でない）運転当番でも棒グラフの色で常時監視できる ように工夫された，実際，立ち上げ時に調整用ビームが入射 されるとビームが進んだ範囲までの真空が（光脱離のため） 悪化し残りの未通過の圧力はバックグラウンド圧力のままと いう画面が見え，ビームモニターが無くてもリングの何処ま でビームが進んだかが一目瞭然となった。電離真空計回路や データ読み取り装置, さらにその表示と記録プログラムの作 成の殆どは北村英男君による開発である.

リングに接続している放射光ビームラインの先にはユー ザーの実験装置が各種配置され，様々なユーザーが多彩な実 験を行っている．中にはミスをして実験装置から放射光ビー ムラインへ，さらにはビームラインからリングヘガスを流し てしまう事故も起こる. 中央制御室では該当ビームラインに 最も近い箇所のリング真空が他に比べ一桁以上悪化（棒グラ 
フの色が変わる）したのを発見し, 実験ホールの担当者へ連 絡をとるというようなことも少なからずあった，入射路の真 空計も含めると 50 台余の真空計の圧力值をいつも頭に記憶 していることはできないが，棒グラフの色で表示されていれ ばパターンとして頭に残りやすく, オペレータは事故などの 異常な圧力上昇をすばやく発見することが格段に容易にな る.このような刻々に取り达んだデータを常時コントロール ルームに表示するシステムも北村英男君が IN-SOR での経 験を活かして構築し, リング運転当番の負担軽減に大きな貢 献をした。

運転とともに圧力データが溜まり，8インチのフロッピー ディスクがすぐ満杯になりハードディスクが必須となった. 真空系の圧力記録を引き出すことで電子ストーレジリングの 性能を(例えば)一年前のそれと比較することが容易になり,
性能向上の一助となった.

$\mathrm{PF}$ 加速器のように長期にわたって信頼性の高い安定な圧 力測定を続けようとしているところは世界的に見ても少ない. CERN では長期的に安定な圧力測定を心がけているようで あるが，他の施設や研究所ではこのような配慮はほとんど見 られなかったと記憶している.

PF リング真空系の基本設計は1978年からスタートし, ビームダクトや排気系の製作・製造，設置に関するいろいろ な工夫を盛り込んでの 3 年間プラス $\alpha$ にたる仕事を紹介 した.リング真空系を構成する各種ハードウェアおよび思わ ぬ故障, その後の PF リングの性能向上については稿を改め て書くことにする.

$(つ つ)$ 